\title{
1 Bistability of mangrove forests and competition with freshwater plants
}

3 Jiang Jiang ${ }^{1}$, Douglas O. Fuller ${ }^{2}$, Su Yean $\mathrm{Teh}^{3}$, Lu Zhai ${ }^{4}$, Hock Lye $\mathrm{Koh}^{5}$, Donald L.

4 DeAngelis ${ }^{4,6}$, Leonel da Silveira Lobo Sternberg ${ }^{4 *}$

$6 \quad{ }^{1}$ National Institute for Mathematical and Biological Synthesis, The University of

7 Tennessee, Knoxville, Tennessee 37996, USA

$8 \quad{ }^{2}$ Department of Geography, University of Miami, Coral Gables, Florida 33124, USA

$9 \quad{ }^{3}$ School of Mathematical Sciences, Universiti Sains Malaysia, Penang 11800, Malaysia

$10{ }^{4}$ Department of Biology, University of Miami, Coral Gables, Florida 33124, USA;

$11{ }^{5}$ Center of Excellence for Research, Value Innovation and Entrepreneurship, UCSI

12 University, Kuala Lumpur 5600, Malaysia

$13{ }^{6}$ Southeast Ecological Science Center, Biological Resources Division, U.S. Geological

14 Survey, Florida USA

15

16 *Corresponding Author: Leo@bio.miami.edu

17

18

19

20 


\section{Abstract}

2 Halophytic communities such as mangrove forests and buttonwood hammocks

3 tend to border freshwater plant communities as sharp ecotones. Most studies attribute this

4 purely to underlying physical templates, such as groundwater salinity gradients caused by

5 tidal flux and topography. However, a few recent studies hypothesize that self-reinforcing

6 feedback between vegetation and vadose zone salinity are also involved and create a

7 bistable situation in which either halophytic dominated habitat or freshwater plant

8 communities may dominate as alternative stable states. Here, we revisit the bistability

9 hypothesis and demonstrate the mechanisms that result in bistability. We demonstrate

10 with remote sensing imagery the sharp boundaries between freshwater hardwood

11 hammock communities in southern Florida and halophytic communities such as

12 buttonwood hammocks and mangroves. We further document from the literature how

13 transpiration of mangroves and freshwater plants respond differently to vadose zone

14 salinity, thus altering the salinity through feedback. Using mathematical models, we show

15 how the self-reinforcing feedback, together with physical template, controls the ecotones

16 between halophytic and freshwater communities. Regions of bistability along

17 environmental gradients of salinity have the potential for large-scale vegetation shifts

18 following pulse disturbances such as hurricane tidal surges in Florida, or tsunamis in

19 other regions. The size of the region of bistability can be large for low-lying coastal

20 habitat due to the saline water table, which extends inland due to salinity intrusion. We

21 suggest coupling ecological and hydrologic processes as a framework for future studies.

22 Keywords: Alternative stable states, transpiration, sharp ecotone, regime shift, storm

23 surge, sea level rise. 


\section{1. Introduction}

2 In tropical and subtropical regions, assemblages of mangrove forests parallel the

3 coastline and riverbanks, transitioning sharply to salt-intolerant plant species, such as

4 hardwood hammocks or freshwater marsh, farther inland. Explanations for the sharpness

5 of the boundary between these two vegetation types have centered on abiotic

6 environmental attributes, such as elevation, salinity, and tidal flooding, as well as biotic

7 processes such as mangrove propagule dispersal and interspecific competition with

8 freshwater plants (Ball, 1980; Davis et al., 2005; Lugo, 1997; Mckee, 1995; Youssef and

9 Saenger, 1999). A widely accepted perspective is that of realized niche differentiation

10 through a combination of abiotic limitation and competition; i.e., freshwater plants cannot

11 survive outside of their physiological salt tolerance range, while mangrove can grow in

12 freshwater as well as saltwater, but do not occur in strictly freshwater environments due

13 to superior competition from freshwater plant species (Krauss et al., 2008; McKee, 2011;

14 Medina et al., 2010; Odum and McIvor, 1990; Sternberg and Swart, 1987). This niche

15 differentiation between halophytic and glycophytic species has been tested in transplant

16 experiments. Transplanted salt marsh species from the intertidal zone to freshwater

17 habitats perform well when competing plants are removed, but are suppressed by

18 competition if freshwater plants are present (Bertness and Ellison, 1987; Cui et al., 2011;

19 Grace and Wetzel, 1981).

20 An implication of the niche differentiation hypothesis is that fitness of mangrove

21 and freshwater plants might be similar over some intermediate range of salinity levels. In

22 this case, one would expect a gradual replacement of mangrove vegetation with

23 freshwater plants as underlying environmental conditions gradually change. Yet there are 
1 sharp ecotones between halophytic forests (mangroves and buttonwood hammock) and

2 freshwater communities, despite extremely gradual changes in topography in some

3 regions, such as coastal areas of southern Florida (Giri et al., 2011; Ross et al., 1992;

4 Saha et al., 2011) and East Africa (Di Nitto et al., 2014). One possible explanation for the

5 sharp ecotones is that the environmental gradient of salinity, determined purely by abiotic

6 factors such as tidal flux, is also sharp, separating salinity tolerant mangroves from the

7 salinity intolerant plants. But this explanation fails to account for the boundaries located

8 at upper intertidal zone, which are seldom inundated by tides; e.g., fringe mangrove

9 forest (Pool et al., 1977).

10 Sternberg et al. (2007) hypothesized that mangrove forests compete with

11 hardwood hammocks as alternative stable states of either pure mangrove forests or pure

12 salt-intolerant hammock species, a case of the general phenomenon of bistability in other

13 systems (Beisner et al., 2003; Holling, 1973; May, 1977; Scheffer et al., 2001).

14 According to the bistability theory, a mixture of the two alternative vegetation types is

15 rarely observed, and an initially mixed system will move towards complete dominance of

16 one or the other type. According to the hypothesis of Sternberg et al. (2007), both

17 mangroves and freshwater plants obtain their water from the vadose zone; that is, the

18 unsaturated soil layer. In coastal areas, this vadose zone is underlain by highly brackish

19 ground water, so that evapotranspiration, by depleting water in this zone during the dry

20 season, can lead to infiltration by more saline ground water (Fass et al., 2007; Passioura

21 et al., 1992; van Duijn et al., 1997). Although freshwater plants tend to decrease their

22 evapotranspiration when vadose zone salinities begin to increase, thus limiting

23 salinization of the vadose zone, mangroves can continue to transpire at relatively high 
1 salinities (Ewe and Sternberg, 2005; Sternberg et al., 2007). Each vegetation type thus

2 tends to promote local salinity conditions that favor itself in competition. This hypothesis

3 of boundary formation through positive feedbacks has been supported through simulation

4 models in which the interactions of vegetation types with each other and with local

5 salinity conditions are simulated (Jiang et al., 2012a; Teh et al., 2008).

6 Until recently, few data have been available to test the bistability hypothesis.

7 Here we link available data on two spatial scales, remote sensing and vegetation

8 physiology, to provide further evidence that the mangrove ecotone pattern at landscape

9 level emerges from lower-level physiological traits. We use remote sensing imagery to

10 analyze spatial patterns of mangrove forests and hardwood hammocks in southern

11 Florida. We also document what is known about the transpiration regime of mangrove in

12 response to soil salinity. A mathematical model (Jiang et al 2012b) is then applied to

13 elucidate the bistability dynamics. In the model environmental factors such as tidal flux,

14 precipitation, evaporation, and soil properties etc., form a physical template that

15 influences the competition between mangrove forest and freshwater plants, especially at

16 the larger spatial scale. Ignoring or downgrading the contribution of physical template

17 would overestimate the role of positive feedback. By including the positive feedback

18 along with the physical template, we provide a framework towards more predictive large-

19 scale vegetation changes.

20 2. Interspersion and juxtaposition of mangroves and hammocks

21 Various landscape metrics have been used to assess spatial relationships between

22 different vegetation types in heterogeneous wetlands and other environments (Fernandes

23 et al., 2011; Guzy et al., 2013; Shoyama and Braimoh, 2011; Stapanian et al., 2013). To 
1 evaluate horizontal interspersion and juxtaposition of hardwood hammocks and

2 mangroves we employed Fragstats version 4.2 software, which is commonly used to

3 analyze spatial patterns within categorical vegetation and land cover maps (Mcgarigal

4 and Ene, 2013). Specifically, we used Fragstats to calculate the Interspersion-

5 Juxtaposition Index (IJI) for an area of southern Everglades National Park where both

6 hammocks and mangroves are found (Figure 1). The IJI provides a measure of patch

7 adjacency and is calculated as:

$8 \quad I J I=\frac{-\sum_{k=1}^{m}\left[\left(\frac{e_{i k}}{\sum_{k=1}^{m} e_{i k}}\right) \ln \left(\frac{e_{i k}}{\sum_{k=1}^{m} e_{i k}}\right)\right]}{\ln (m-1)} \times 100$

9 where $e_{i k}$ is the total length (in meters) of edge in a landscape with classes $i$ and $k$, and $m$

10 is the number of classes present in the landscape, $m=3$ in this study with hammocks,

11 mangroves and others. $I J I$ approaches 0 when the corresponding patch type is adjacent to

12 same patch type and increases when a class shares a border with other classes. Further,

13 when $I J I=100$ the corresponding each patch type is equally adjacent to all other patch

14 types or maximally interspersed (or intermixed) and juxtaposed to other patch types

15 (Mcgarigal and Ene, 2013).

16 We obtained categorical vegetation data from the Florida Coastal Everglades

17 Long-Term Ecological Research (LTER) website

18 http://fcelter.fiu.edu/data/GIS/?layer=vegetation\#layer, which provides highly detailed

19 data mapped using high-resolution aerial and satellite images (Welch et al., 1999). GPS-

20 assisted accuracy check was an average of $90 \%$ correct, with resolution of $10 \mathrm{~m}$. The map

21 delineates eight mangrove forest subtypes including stands dominated by Red mangrove

22 (Rhizophora mangle), White Mangrove (Laguncularia racemosa), Black mangroves

23 (Avicennia germinans), and Buttonwood (Conocarpus erectus) as well as various 
1 mixtures of these subtypes. These classes were aggregated into a single mangrove class to

2 simplify the analysis of IJI. Similarly, Welch et al. (1999) also distinguished a number of

3 hardwood vegetation types, including subtropical hardwood forest, mixed hardwood

4 swamp forest, mixed hardwoods and bayheads, which were also aggregated into a single

5 hardwood class (Figure 1). All other vegetation types in the map were considered as

6 'other vegetation' or background, which was dominated mainly by graminoid vegetation

7 types such as sawgrass marsh (Cladium jamaicense).

$8 \quad$ The results from Fragstats reveal values of $I J I$ of 13.49 and 37.55 for mangroves

9 and hardwoods respectively. These values suggest that mangroves are not highly

10 intermixed and that hardwoods are moderately interspersed and juxtaposed to mangroves.

11 This finding is likely explained in part by the dominance of mangroves relative to

12 hardwoods in the area analyzed (Figure 1). In comparison to ecological studies in other

13 regions that have employed the $I J I$ metric, the two main vegetation types in this portion

14 of the southern Everglades appear to have relatively high adjacency. For example, Coops

15 et al. (2010) showed that in a disturbed boreal forest landscape, IJI ranged from

16 approximately $35-60$ over a period of 14 years during which forest fragmentation

17 increased. Further, Guzy et al. (2013) showed that mean IJI ranged from 7.2 to 65.3 for a

18 range of aquatic vegetation types found across different rural to urban environments. In

19 general, the literature suggests that $I J I$ values are somewhat lower in wetlands than for

20 terrestrial ecosystems (consistent with sharp zonation patterns that characterize coastal

21 wetlands), although a systematic comparative study of $I J I$ values across a range of

22 ecosystems appears to be lacking (Cifaldi et al., 2004; Li et al., 2010; Torbick et al.,

23 2006). Nonetheless, the $I J I$ metric as well as Figure 1 suggest mangroves tend to be 
1 relative clumped rather than intermixed with hardwood hammocks. Although there are

2 uncertainties of what cause the bistability, sharp boundaries between mangroves and

3 hardwood hammocks are consistent with the hypothesis advanced by Sternberg et al.

4 (2007).

\section{3. Mechanisms of bistability}

6 Fundamental to the bistability hypothesis (Jiang et al., 2012a; 2012b; Sternberg et

7 al., 2007; Teh et al., 2008) is the assumption that during the dry season mangroves will

8 continue to transpire despite the high salinity of the vadose zone, causing capillary rise of

9 saline water from water table and a consequent increase the salinity of the vadose zone.

10 Freshwater plants during the dry season, on the other hand, will decrease or cease

11 transpiration, thus maintaining a low salinity of the vadose zone. Precipitation plays a

12 role also, reducing vadose zone salinity in both habitat types during the wet season, but

13 dry season salinity is the major determinant of vegetation type and is much higher under

14 mangrove vegetation (Fass et al., 2007; Saha et al., 2012). Here we compare transpiration

15 regimes of the two plant types responding to vadose zone salinity and demonstrate how

16 the differential transpiration regimes influence vadose zone salinity. A simple

17 mathematical model that can capture the mechanism is presented to describe population

18 dynamics at the landscape scale, showing how bistability can emerge from functional

19 traits of transpiration response to salinity and the ability of mangrove alter soil salinity

20 patterns.

\section{$21 \quad 3.1$ Physiological level transpiration regime}

22 Effects of water stress caused by salinity on transpiration reduction are well

23 documented in salt-sensitive plants (Achenbach et al., 2013; Meiri and Poljakoff-Mayber, 
1 1970; Volkmar et al., 1998). When dissolved salt concentrations in soil increase, water

2 potential gradients from soil to plant root decrease, lowering the water movement from

3 the soil through root membranes and into the plant. In addition to this osmotic effect, ion

4 flux to shoots causes stomatal closure (Hasegawa et al., 2000). Coastal freshwater plants

5 may tolerate short periods of high salinity, by ceasing or diminishing transpiration during

6 the dry season and resuming transpiration when precipitation increases and washes

7 salinity from the soil. In a South Carolina watershed, for example, baldcypress

8 (Taxodium distichum) reduces water uptake by more than $75 \%$ as a response to short-

9 term salinity stress (Krauss and Duberstein, 2010). In the saline southeastern Everglades

10 ecotone, sawgrass (Cladium jamaicense) may survive for short episodes of exposure to

11 high salinities during the dry season (Ewe et al., 2007), despite sawgrass annual net

12 primary productivity declining when salinity increases (Childers et al., 2006).

13 The status of sapflow or transpiration of mangroves in response to salinity is still

14 a controversial topic, although there is agreement that mangroves can tolerate high

15 salinities in the rhizosphere through salt exclusion, salt secretion and salt accumulation

16 (Tomlinson, 1994). Mangroves may reduce transpiration in response to salinity increases,

17 indicating conservative rates of water use (Becker et al., 1997; Krauss et al., 2012). By

18 extensive literature review (see Appendix for the method), however, we show that in

19 mangroves, species with higher salt tolerance display less reduction in transpiration

20 (Figure 2). Tolerant and very tolerant species reduce transpiration $28 \%$ and $13 \%$,

21 respectively, in response to per $10 \mathrm{ppt}$ salinity increase. We did not analyze the responses

22 of all freshwater plant species to salinity, but in general we can say that most salt-

23 sensitive species cannot survive above 10 ppt. By comparing native southern Florida 
1 glycophytic species to mangroves, Ewe and Sternberg (2005) found reductions of 54\%

2 and $15 \%$ in stomatal conductance for glycophytic species Randia aculeata and the

3 mangrove R. mangle, respectively. Evapotranspiration (ET) in a mangrove dominated

4 area is also much higher than in an equivalent sawgrass area, and is the largest water loss

5 in an estuary wetland, as estimated by a water budget model (Saha et al., 2012).

6 Based on the differential transpiration regimes described above, mangrove and

7 freshwater plants have different abilities to change salinities of soil porewater through

8 transpiration. Less reduction in water uptake of mangroves at high salinity conditions can

9 lead to vadose zone salinity increases (Passioura et al., 1992; van Duijn et al., 1997). Fass

10 et al. (2007) demonstrated that mangrove forests could lead to high chloride

11 concentrations in ground water; for example, in an Australian river delta chloride

12 concentration was almost three times that of ocean water.

\section{$13 \quad 3.2$ Scale to landscape level vegetation competition}

14 When one considers the ability of mangroves to change vadose zone salinity,

15 competition between mangroves and freshwater plants becomes a complex issue.

16 Hardwood hammock species are competitively superior in low salinity areas, suggesting

17 that halophytic species will usually be excluded from areas farther from tidal influence by

18 competitive exclusion (Kenkel et al., 1991; La Peyre et al., 2001; Silander and

19 Antonovics, 1982). In areas of intermediate salinity, however, mangrove vegetation,

20 once established, can influence vadose zone salinity in its favor. Alternatively, hardwood

21 hammocks, when in high abundance, can compete effectively with mangroves and

22 maintain low salinity. Thus the distribution of the two plant types is controlled by a

23 combination of the externally imposed physical template and emergent self-organization 
1 (Sheffer et al., 2013). Over a certain range of this physical template, feedbacks between

2 mangroves and freshwater plants can affect soil salinity and result in bistability (Figure

33$.$) .$

$4 \quad$ Jiang et al. (2012b) developed a simple mathematical model integrating the

5 feedbacks between halophytic and glycophytic vegetation to a physical template of

6 baseline salinity gradient. These equations describe the change in biomass of mangroves

$7 \quad(d M / d t)$, freshwater plants $(d F / d t)$, and the pore water salinity $(d S / d t)$ on a unit time step

8 (e.g. per year). Change of mangrove biomass is a function of standing mangrove biomass

$9(M)$ and its maximum relative growth rate $(\rho)$, modulated by salinity stress $\left(m_{(s)}\right)$ and

10 intraspecific $\left(\alpha_{M M} M\right)$ or interspecific $\left(\alpha_{M F} F\right)$ competition. Likewise, change of

11 freshwater plant biomass is modulated by salinity stress $\left(f_{(S)}\right)$, intraspecific $\left(\alpha_{F F} F\right)$ and

12 interspecific $\left(\alpha_{F M} M\right)$ competition.

$$
\frac{d M}{d \tilde{t}}=M\left(\rho m_{(S)}-\alpha_{M M} M-\alpha_{M F} F\right)
$$

$$
\frac{d F}{d \tilde{t}}=F\left(\rho f_{(S)}-\alpha_{F F} F-\alpha_{F M} M\right)
$$

15 where, equations (2) and (3) constitute a classic Lotka-Volterra two-species competition 16 model.

17 The increase in soil salinity $(S)$ can be described in terms of salinity infiltration

18 upwards into the vadose zone from the saline water table $(g)$ through capillary action,

19 replacing soil water that is lost through evaporation at a rate $\beta_{0} g$, which is equal to

20 ground water salinity times the coefficient $\beta_{0}$. We assume that water table salinity, $g$, has

21 a spatial gradient along the physical template, increasing from inland towards the coast,

22 and is not affected by plants. Additional salinity increases in the vadose zone by

23 mangrove plants follow a Monod equation $\left(\frac{\beta_{1} M}{\tilde{k}+M} g\right)$ with a maximum rate of $\beta_{1}$ and half- 
1 saturation coefficient $k$. The salinity increase is countered by salinity washout $(\varepsilon S)$ due to

2 precipitation or other freshwater inputs at a rate of $\varepsilon$. The equation describing vadose

3 zone salinity can thus be written as

$4 \quad \frac{d S}{d \tilde{t}}=\beta_{0} g+\frac{\beta_{1} M}{\tilde{k}+M} g-\varepsilon S$.

5 All parameter values are positive and the same as in Jiang et al. (2012b). The

6 model can be shown to imply, along a certain range of values of $g$, the possibility of

7 alternative stable states of either a high salinity state dominated by mangroves or a low

8 salinity state dominated by freshwater plants in a three-dimensional 'stability landscape'

9 (Figure 4). In the sense of the familiar stability landscape in the form of 'valley' and

10 'hilltop' (Walker et al., 2004), the 3D stability landscape, or state space, has two regions

11 separated by a boundary, or separatrix. The ball can settle to a stable equilibrium in each

12 region, having some degree of resilience to perturbations. These regions are called

13 'basins of attraction' in mathematics. The larger the size of the basin of attraction, and the

14 steeper its slope, the more resilience the system has to a perturbation away from the

15 stable state within that basin. However, a disturbance that is large enough can cause the

16 ball to cross over the separatrix from one basin of attraction to the other one, which will

17 result in a regime shift.

18 The possibility of alternative stable states occurs only over a certain range of the

19 physical template, or values of water table salinity, $g$ (Figure 4), which can be imagined

20 as a transect from the ocean side, with high water table salinity, to an inland point with

21 much lower groundwater salinity. At both ends of the physical template, that proximate

22 to the ocean side and the inland end of the transition, only one stable state exists. This can

23 be explained by the niche differentiation hypothesis, that freshwater plant cannot tolerate 
1 high salinity; and that mangroves are excluded by competition at low salinity end. Over a

2 certain range of water table salinities, however, a bistable region that can be,

3 alternatively, either mangroves or freshwater plants, exists; but the relative resilience of

4 each state is controlled by details of the physical template. Analysis of equations (2), (3)

5 and (4) provides a theoretical range of the physical template over which bistability exists,

6 but the actual size of the range depends on a whole complex of factors that are not

7 explicit in the model; abiotic factors such as precipitation, landscape morphology, and

8 depth and salinity of the water table; and biotic factors such as the physiological and

9 competitive properties of local vegetation and age or size class of plants. Jiang et al.

10 (2012a) developed a more complex spatially explicit, individual-based simulation model

11 to disentangle the relative contributions of the physical template and bistability

12 mechanism in the formation of sharp ecotone. This model was based on a simpler

13 spatially explicit model, MANHAM (Sternberg et al, 2007; Teh et al., 2008), in which

14 vegetation was not modeled as individual-based, but as state variables representing

15 fractional occupation of spatial cells. The model of Jiang et al. (2012a) uses parameters

16 estimated from general mangrove types, and the same simplified hydrology process as

17 the original MANHAM used. The emergence of bistability suggests that including

18 positive feedback mechanism in more realistic hydrology models is necessary to provide

19 more realistic predictions of vegetation changes.

\section{4. Implication for large-scale vegetation changes}

21 Much of what has been documented concerning the spatial and temporal shifts of

22 mangroves along coastal habitats can be explained by gradual environmental changes

23 (Berger et al., 2008; Chen and Twilley, 1998; Doyle et al., 2003). Sea level rise and 
1 anthropogenic decreases in freshwater flow cause salinity intrusion and a landward shift

2 of the mangrove bands. For example, Doyle et al. (2003) used computer simulations to

3 project possible inland migration of mangroves along the southern Florida coastline in

4 response to sea level rise. This was done using projections of the inland movement of

5 tidal influence, given the topography of southern Florida. However, even if locations of

6 spatial location of mean tidal influence does not change in the future, the bistability

7 hypothesis implies that sufficiently large storm surge disturbances, if they maintain salt

8 intrusion for some time period, could still result in an inland shift in mangroves beyond

9 what would be predicted from sea level rise alone. This could happen if the resultant

10 salinity input to freshwater habitat is large enough to tip an existing stable freshwater

11 vegetation state to the alternative mangrove stable state. The model MANHAM (Teh et

12 al. 2008) simulated competition between mangroves and hardwood hammock vegetation

13 on two-dimensional grid of square spatial cells, where the sides of each cell were

14 assumed to be in the range of a few to several meters. Vadose zone salinity in each cell

15 was modeled as a function of tidal flux, precipitation, groundwater salinity, and

16 evapotranspiration. The two vegetation types were represented as state variable for

17 fractions occupying each cell. From simulations of MANHAM it was found that in the

18 event of a light surge, accompanied by mangrove propagules, hardwood hammocks were

19 able to restore the salinity to low levels in a short time period. After 50 years, hardwood

20 hammocks still dominated the cells at higher elevation but the patches of mangrove-

21 dominated cells were larger compared to the case without a storm surge event. A medium

22 surge event that saturated the vadose zone at $15 \mathrm{ppt}$ caused the mangroves to invade the

23 cells at higher elevation that were initially dominated by hardwood hammocks. A heavy 
1 surge caused the mangroves to take over the entire domain inundated by the surge after

250 years. Therefore, consistent with the bistability hypothesis, simulations with

3 MANHAM indicated that broad areas of hardwood hammocks could theoretically

4 undergo regime shift to mangrove vegetation under a single sufficiently large storm surge

5 (Sternberg et al., 2007; Teh et al., 2008; Williams et al., 2003).

6 Mechanisms of ecological bistability influenced by environmental gradients,

7 especially salinity gradients caused by tidal flux, should be considered in the study of

8 large-scale vegetation changes. Within the region of bistability, exact location of the

9 ecotone between the two vegetation states depends on initial conditions; i.e., which

10 vegetation type got there first. Although the ecotone within the region of bistability can

11 change as a result of large perturbations, it may be fairly resilient to small disturbances

12 caused by sea level rise or minor storm surges. Jiang et al. (2014) apply the model to a

13 section of the mangrove-freshwater marsh ecotone on the southwestern coast of the

14 Everglades. Based on recorded data from Hurricane Wilma at a USGS monitoring site,

15 the model indicated that salinity at that site would probably persist in the soil for only a

16 short period of time after the hurricane, and the model projected that the ecotone would

17 be resilient to that minor disturbance. But scenarios of longer period of salinity intrusion

18 and passive transports of mangrove propagules via storm surge could cause a shift of

19 freshwater marsh to mangrove forest.

20 Whether such storm-surge induced pulses could lead to long-term effects on

21 vegetation depend on many factors: the physiological and competitive properties of local

22 vegetation, precipitation, overland freshwater flow, elevation gradient, and depth and

23 salinity of groundwater. Thus, predicting the likelihood of such shifts requires detailed 
1 modeling of coupled ecological-hydrologic processes. Coupling vegetation dynamics

2 with underling environmental models is a state-of-the-art of modeling approach and

3 depends on spatial scale (Runyan et al., 2012). At the scale of individual trees, salinity

4 can affect plant transpiration, but individual plants hardly change soil salinity, as the

5 effect of a single plant is overwhelmed by regional hydrological dynamics. At a larger

6 scale, an assembly of mangrove forests may exert strong engineering force on vadose

7 zone salinity. Our modeling framework suggests hydrology models that take into account

8 the balance of physical template and positive feedback between plants and soil conditions

9 could determine how large a spatial scale the bistability pattern would emerge.

\section{5. Concluding remarks and future direction}

11 We demonstrated here how interactions between mangroves, freshwater plants

12 and local soil conditions could result in bistability along an environmental gradient of

13 water table salinity. Sharp ecotones are usually indicators of positive feedbacks that cause

14 bistability between differing vegetation types, such as forest-grassland, forest-mire,

15 Alpine treelines, etc. (Agnew et al., 1993; Wiegand et al., 2006). The mangrove forest -

16 salt marsh transitions are also suggested to result from positive feedback between

17 vegetation and local temperature (D'Odorico et al., 2013). But abrupt spatial changes

18 between two vegetation types are not always evidence for bistability (Wilson and Agnew,

19 1992). Peterson (1984) pointed out "Only by experiment could one convincingly

20 demonstrate multiple stable states by showing that the very same site could come to be

21 occupied by different, self-replicating communities". But the "very same site" condition

22 is difficult to prove in this case since feedback loops driven by mangrove alter the salinity

23 conditions. Wet season salinity, which is least influenced by vegetation, might be a good 
1 candidate for a criterion for comparing similar sites. Sites with the same wet season

2 salinity, assuming other factors are same as well, will insure that the observed difference

3 in salinity of the vadose zone at the end of the dry season is caused by the presence of the

4 particular plant functional type that occurs there and not by other factors.

5 The bistability hypothesis is proposed based on the fundamental assumption that

6 differential transpiration regimes of the particular plant functional type in response to

7 salinity, and the ability for this to influence salinity of the vadose zone. Although

8 empirical studies support this assumption, no direct experimental data are available to

9 derive the response function. Furthermore, daily ET values at landscape level are highly

10 dependent on the level of solar radiation. Future theoretical and empirical studies should

11 consider seasonality of radiation on the response function of transpiration to salinity.

12 Identification of the region of bistability is necessary for projecting large-scale

13 vegetation changes as well as for developing potential management plans. The lower

14 intertidal zone is limited to halophytic vegetation, while on higher elevation land inland

15 that lacks frequent salinity overwash or a saline water table, freshwater plants are always

16 competitively dominant. However, the coastal Everglades and the Florida Keys contain

17 large areas of saline water table, which provide potential areas for region of bistability.

18 Accurate predictions of bistability will require sophisticated hydrology models coupled

19 with landscape vegetation dynamics.

20

\section{Acknowledgements}

22 We appreciate two reviewers for insightful comments on this manuscript. JJ was

23 supported as Postdoctoral Fellow at the National Institute for Mathematical and 
1 Biological Synthesis (NSF Award \#DBI-1300426) with additional support from The

2 University of Tennessee, Knoxville. DOF and LSLS were supported by the NASA Water

3 SCAPES (Science of Coupled Aquatic Processes in Ecosystems from Space) Grant

4 NNX08BA43A. DLD was partially supported by the FISCHS Project (Future Impacts of

5 Sea Level Rise on Coastal Habitats and Species) at the USGS Southeast Ecological

6 Science Center, funded by USGS Ecosystems Mapping and the USGS Greater

7 Everglades Priority Ecosystems Science. SYT and HLK were partially supported by the 8 grants 305/PMATHS/613418 and 203/PMATHS/6730101.

9

10 


\section{Appendix: Meta-analysis based on literature review on transpiration of mangroves}

\section{2 in response to salinity}

3 Using a meta-analysis approach, we assessed if mangroves reduce transpiration in

4 response to salinity increases. We conducted a literature search on Web of Knowledge

5 and Google Scholar, using combinations of the search terms mangrove, salinity and any

6 of terms with sap flow, transpiration, stomatal conductance, shoot evaporation or water

7 use. After screening the initial list of over 800 articles generated by our data base

8 searches, we retained only studies that measured water-related characteristics at multiple

9 salinity levels. Most of studies measured stomatal conductance; there were relatively few

10 with direct data on transpiration, shoot evaporation or sap flow. We extracted raw data

11 from tables or scatter plots using GETDATA GRAPH DIGITIZER 2.24 (Fedorov, 2013).

12 Since reduction of stomatal conductance follows the same pattern as transpiration in

13 response to salinity increase (Youssef, 2007), we calculated the dimensionless percent of

14 reduction in response to $10 \mathrm{ppt}$ increases of salinity. From all the studies, we extracted 27

15 articles with 32 tests of hydrologic characteristics in response to salinity changes, which

16 were reported for 16 species. Relative tolerances of the species were classified as very

17 tolerant and tolerant modified from Clough (1992). 


\section{References:}

2 Achenbach, L., Eller, F., Nguyen, L.X. and Brix, H., 2013. Differences in salinity

3 tolerance of genetically distinct Phragmites australis clones. AoB Plants, 5: doi:

$4 \quad$ 10.1093/aobpla/plt019.

5 Agnew, A.D.Q., Wilson, J.B. and Sykes, M.T., 1993. A vegetation switch as the cause of

6 a forest/mire ecotone in New Zealand. Journal of Vegetation Science, 4(2): 273-

$7 \quad 278$.

8 Ball, M.C., 1980. Patterns of secondary succession in a mangrove forest of Southern

$9 \quad$ Florida. Oecologia, 44(2): 226-235.

10 Ball, M.C., 1988. Salinity tolerance in the mangroves Aegiceras corniculatum and

11 Avicennia marina. 1. Water-use in relation to growth, carbon partitioning, and salt

12 balance. Australian Journal of Plant Physiology, 15(3): 447-464.

13 Ball, M.C., Cochrane, M.J. and Rawson, H.M., 1997. Growth and water use of the

14 mangroves Rhizophora apiculata and R-stylosa in response to salinity and

15 humidity under ambient and elevated concentrations of atmospheric CO2. Plant

16 Cell and Environment, 20(9): 1158-1166.

17 Ball, M.C. and Munns, R., 1992. Plant responses to salinity under elevated atmospheric

18 concentrations of CO2. Australian Journal of Botany, 40(4-5): 515-525.

19 Becker, P., Asmat, A., Mohamad, J., Moksin, M. and Tyree, M.T., 1997. Sap flow rates

20 of mangrove trees are not unusually low. Trees-Structure and Function, 11(7):

$21 \quad 432-435$.

22 Beisner, B.E., Haydon, D.T. and Cuddington, K., 2003. Alternative stable states in

23 ecology. Frontiers in Ecology and the Environment, 1(7): 376-382. 
1 Berger, U., Rivera-Monroy, V.H., Doyle, T.W., Dahdouh-Guebas, F., Duke, N.C.,

2 Fontalvo-Herazo, M.L., Hildenbrandt, H., Koedam, N., Mehlig, U., Piou, C. and

3 Twilley, R.R., 2008. Advances and limitations of individual-based models to

4 analyze and predict dynamics of mangrove forests: A review. Aquatic Botany, $5 \quad$ 89(2): 260-274.

6 Bertness, M.D. and Ellison, A.M., 1987. Determinants of pattern in a New England salt 7 marsh plant community. Ecological Monographs, 57(2): 129-147.

8 Chen, R.G. and Twilley, R.R., 1998. A gap dynamic model of mangrove forest

9 development along gradients of soil salinity and nutrient resources. Journal of

$10 \quad$ Ecology, 86(1): 37-51.

11 Childers, D., Iwaniec, D., Rondeau, D., Rubio, G., Verdon, E. and Madden, C., 2006.

12 Responses of sawgrass and spikerush to variation in hydrologic drivers and

13 salinity in Southern Everglades marshes. Hydrobiologia, 569(1): 273-292.

14 Cifaldi, R.L., David Allan, J., Duh, J. and Brown, D.G., 2004. Spatial patterns in land

15 cover of exurbanizing watersheds in southeastern Michigan. Landscape and

16 Urban Planning, 66(2): 107-123.

17 Clough, B., 1992. Primary productivity and growth of mangrove forests. Coastal and

18 Estuarine Studies, 41: 225-249.

19 Clough, B.F. and Sim, R.G., 1989. Changes in gas-exchange characteristics and water-

20 use efficiency of mangroves in response to salinity and vapor-pressure deficit.

$21 \quad$ Oecologia, 79(1): 38-44. 
1 Cui, B., He, Q., Zhang, K. and Chen, X., 2011. Determinants of annual-perennial plant zonation across a salt-fresh marsh interface: a multistage assessment. Oecologia, 166(4): 1067-1075.

4 D'Odorico, P., He, Y., Collins, S., De Wekker, S.F., Engel, V. and Fuentes, J.D., 2013. Vegetation-microclimate feedbacks in woodland-grassland ecotones. Global

$6 \quad$ Ecology and Biogeography, 22(4): 364-379.

7 Davis, S.M., Childers, D.L., Lorenz, J.J., Wanless, H.R. and Hopkins, T.E., 2005. A

8 conceptual model of ecological interactions in the mangrove estuaries of the

$9 \quad$ Florida Everglades. Wetlands, 25(4): 832-842.

10 Di Nitto, D., Neukermans, G., Koedam, N., Defever, H., Pattyn, F., Kairo, J.G. and

11 Dahdouh-Guebas, F., 2014. Mangroves facing climate change: landward

12 migration potential in response to projected scenarios of sea level rise.

13 Biogeosciences, 11: 857-871.

14 Doyle, T.W., Girod, G.F. and Brooks, M.A., 2003. Modeling mangrove forest migration

15 along the southwest coast of Florida under climate change. In: Z.H. Ning, R.E.

16 Turner, T.W. Doyle and K. Abdollahi (Editors), Integrated Assessment of the Climate Change Impacts on the Gulf Coast Region. GRCCC and LSU Graphic

18 Services, Baton Rouge, LA, pp. 211-221.

19 Ewe, S. and Sternberg, L.D.L., 2005. Growth and gas exchange responses of Brazilian 20 pepper (Schinus terebinthifolius) and native South Florida species to salinity.

21 Trees-Structure and Function, 19(2): 119-128.

22 Ewe, S.M.L., Sternberg, L.D.S.L. and Childers, D.L., 2007. Seasonal plant water uptake 23 patterns in the saline southeast Everglades ecotone. Oecologia, 152(4): 607-616. 
1 Fass, T., Cook, P.G., Stieglitz, T. and Herczeg, A.L., 2007. Development of saline ground water through transpiration of sea water. Ground Water, 45(6): 703-710.

3 Fedorov, S., 2013. GetData Graph Digitizer version 2.26., http://getdata-graph-

$4 \quad$ digitizer.com.

5 Fernandes, M.R., Aguiar, F.C. and Ferreira, M.T., 2011. Assessing riparian vegetation

6 structure and the influence of land use using landscape metrics and geostatistical 7 tools. Landscape and Urban Planning, 99(2): 166-177.

8 Giri, C., Ochieng, E., Tieszen, L., Zhu, Z., Singh, A., Loveland, T., Masek, J. and Duke, 9 N., 2011. Status and distribution of mangrove forests of the world using earth 10 observation satellite data. Global Ecology and Biogeography, 20(1): 154-159.

11 Grace, J.B. and Wetzel, R.G., 1981. Habitat partitioning and competitive displacement in 12 Cattails (Typha): Experimental field studies. The American Naturalist, 118(4): $13 \quad 463-474$.

14 Guzy, J.C., Price, S.J. and Dorcas, M.E., 2013. The spatial configuration of greenspace

15 affects semi-aquatic turtle occupancy and species richness in a suburban 16 landscape. Landscape and Urban Planning, 117: 46-56.

17 Hasegawa, P.M., Bressan, R.A., Zhu, J.-K. and Bohnert, H.J., 2000. Plant cellular and 18 molecular responses to high salinity. Annual review of plant biology, 51(1): 46319499.

20 Holling, C.S., 1973. Resilience and stability of ecological systems. Annual Review of $21 \quad$ Ecology and Systematics, 4: 1-23.

22 Jiang, J., DeAngelis, D., Smith, T., Teh, S. and Koh, H.-L., 2012a. Spatial pattern 23 formation of coastal vegetation in response to external gradients and positive 
feedbacks affecting soil porewater salinity: a model study. Landscape Ecology,

$27(1): 109-119$.

3 Jiang, J., DeAngelis, D.L., Anderson, G.H. and Smith III, T.J., 2014. Analysis and

4 Simulation of Propagule Dispersal and Salinity Intrusion from Storm Surge on the

5 Movement of a Marsh-Mangrove Ecotone in South Florida. Estuaries and Coasts, $6 \quad 37(1): 24-35$.

7 Jiang, J., Gao, D. and DeAngelis, D.L., 2012b. Towards a theory of ecotone resilience:

8 Coastal vegetation on a salinity gradient. Theoretical Population Biology, 82(1):

$927-37$.

10 Kao, W.Y., Tsai, H.C. and Tsai, T.T., 2001. Effect of $\mathrm{NaCl}$ and nitrogen availability on 11 growth and photosynthesis of seedlings of a mangrove species, Kandelia candel

12 (L.) Druce. Journal of Plant Physiology, 158(7): 841-846.

13 Kenkel, N.C., McIlraith, A.L., Burchill, C.A. and Jones, G., 1991. Competition and the 14 response of 3 plant-species to a salinity gradient. Canadian Journal of Botany, 15 69(11): 2497-2502.

16 Krauss, K.W. and Duberstein, J.A., 2010. Sapflow and water use of freshwater wetland 17 trees exposed to saltwater incursion in a tidally influenced South Carolina 18 watershed. Canadian Journal of Forest Research, 40(3): 525-535.

19 Krauss, K.W., Lovelock, C.E., McKee, K.L., Lopez-Hoffman, L., Ewe, S.M.L. and 20 Sousa, W.P., 2008. Environmental drivers in mangrove establishment and early 21 development: A review. Aquatic Botany, 89(2): 105-127. 
1 Krauss, K.W., McKee, K.L. and Hester, M.W., 2012. Water use characteristics of black mangrove (Avicennia germinans) communities along an ecotone with marsh at a northern geographical limit. Ecohydrology: doi: 10.1002/eco.1353.

4 La Peyre, M.K.G., Grace, J.B., Hahn, E. and Mendelssohn, I.A., 2001. The importance of competition in regulating plant species abundance along a salinity gradient.

$6 \quad$ Ecology, 82(1): 62-69.

7 Li, Y., Zhu, X., Sun, X. and Wang, F., 2010. Landscape effects of environmental impact on bay-area wetlands under rapid urban expansion and development policy: a case study of Lianyungang, China. Landscape and Urban Planning, 94(3): 218-227.

Lin, G. and Sternberg, L.D.L., 1992. Effect of growth form, salinity, nutrient and sulfide on photosynthesis, carbon isotope discrimination and growth of red mangrove (Rhizophora mangle L. Australian Journal of Plant Physiology, 19(5): 509-517.

Lopez-Hoffman, L., Anten, N.P.R., Martinez-Ramos, M. and Ackerly, D.D., 2007. Salinity and light interactively affect neotropical mangrove seedlings at the leaf

20 Lovelock, C.E., Ball, M.C., Feller, I.C., Engelbrecht, B.M.J. and Ewe, M.L., 2006.

21 Variation in hydraulic conductivity of mangroves: influence of species, salinity, 22 and nitrogen and phosphorus availability. Physiologia Plantarum, 127(3): 457464. 
1 Lugo, A.E., 1997. Old-growth mangrove forests in the United States. Conservation Biology, 11(1): 11-20.

3 May, R.M., 1977. Thresholds and breakpoints in ecosystems with a multiplicity of stable $4 \quad$ states. Nature, 269(5628): 471-477.

5 Mcgarigal, K. and Ene, E., 2013. Fragstats 4.2: A spatial pattern analysis program for 6 categorical maps, University of Massachusetts, Amherst, $7 \quad$ http://www.umass.edu/landeco/research/fragstats/fragstats.html.

8 Mckee, K.L., 1995. Seedling recruitment patterns in a Belizean mangrove forest - effects

9 of establishment ability and physicochemical factors. Oecologia, 101(4): 448-460.

10 McKee, K.L., 2011. Biophysical controls on accretion and elevation change in Caribbean 11 mangrove ecosystems. Estuarine, Coastal and Shelf Science, 91(4): 475-483.

12 Medina, E., Cuevas, E. and Lugo, A.E., 2010. Nutrient relations of dwarf Rhizophora 13 mangle L. mangroves on peat in eastern Puerto Rico. Plant ecology, 207(1): 131424.

15 Meiri, A. and Poljakoff-Mayber, A., 1970. Effect of various salinity regimes on growth, 16 leaf expansion and transpiration rate of bean plants. Soil Science, 109(1): 26-34.

17 Muller, E., Lambs, L. and Fromard, F., 2009. Variations in water use by a mature 18 mangrove of Avicennia germinans, French Guiana. Annals of Forest Science, $19 \quad 66(8)$.

20 Naidoo, G. and Vonwillert, D.J., 1995. Diurnal gas-exchange characteristics and water21 use efficiency of 3 salt-secreting mangroves at low and high salinities.

22 Hydrobiologia, 295(1-3): 13-22. 
1 Odum, W.E. and McIvor, C.C., 1990. Mangroves. In: R.L. Myers and J.J. Ewel (Editors), Ecosystems of Florida. University of Central Florida Press, Orlando, pp. 517-548.

3 Passioura, J.B., Ball, M.C. and Knight, J.H., 1992. Mangroves may salinize the soil and $4 \quad$ in so doing limit their transpiration rate. Functional ecology, 6(4): 476-481.

5 Peterson, C.H., 1984. Does a rigorous criterion for environmental identity preclude the 6 existence of multiple stable points? The American Naturalist, 124(1): 127-133.

7 Pool, D.J., Snedaker, S.C. and Lugo, A.E., 1977. Structure of mangrove forests in

8 Florida, Puerto-Rico, Mexico, and Costa-Rica. Biotropica, 9(3): 195-212.

9 Reef, R., Schmitz, N., Rogers, B.A., Ball, M.C. and Lovelock, C.E., 2012. Differential

10 responses of the mangrove Avicennia marina to salinity and abscisic acid.

11 Functional Plant Biology, 39(12): 1038-1046.

12 Ross, M.S., O'Brien, J.J. and Flynn, L.J., 1992. Ecological site classification of Florida

13 Keys terrestrial habitats. Biotropica, 24(4): 488-502.

14 Runyan, C.W., D'Odorico, P. and Lawrence, D., 2012. Physical and biological feedbacks 15 of deforestation. Reviews of Geophysics, 50(4).

16 Saha, A., Moses, C., Price, R., Engel, V., Smith, T., III and Anderson, G., 2012. A

17 hydrological budget (2002-2008) for a large subtropical wetland ecosystem

18 indicates marine groundwater discharge accompanies diminished freshwater flow.

$19 \quad$ Estuaries and Coasts, 35(2): 459-474.

20 Saha, A., Saha, S., Sadle, J., Jiang, J., Ross, M., Price, R., Sternberg, L. and

21 Wendelberger, K., 2011. Sea level rise and South Florida coastal forests. Climatic

22 Change, 107(1): 81-108. 
1 Santiago, L.S., Lau, T.S., Melcher, P.J., Steele, O.C. and Goldstein, G., 2000. Morphological and physiological responses of Hawaiian Hibiscus tiliaceus populations to light and salinity. International Journal of Plant Sciences, 161(1): 99-106.

5 Scheffer, M., Carpenter, S., Foley, J.A., Folke, C. and Walker, B., 2001. Catastrophic 6 shifts in ecosystems. Nature, 413(6856): 591-596.

7 Sheffer, E., Hardenberg, J., Yizhaq, H., Shachak, M. and Meron, E., 2013. Emerged or 8 imposed: a theory on the role of physical templates and self- organisation for $9 \quad$ vegetation patchiness. Ecology letters, 16(2): 127-139.

10 Shoyama, K. and Braimoh, A.K., 2011. Analyzing about sixty years of land-cover change 11 and associated landscape fragmentation in Shiretoko Peninsula, Northern Japan. 12 Landscape and Urban Planning, 101(1): 22-29.

13 Silander, J.A. and Antonovics, J., 1982. Analysis of interspecific interactions in a coastal 14 plant community: A perturbation approach. Nature, 298(5874): 557-560.

15 Sobrado, M.A., 1999. Leaf photosynthesis of the mangrove Avicennia germinans as 16 affected by NaCl. Photosynthetica, 36(4): 547-555.

17 Sobrado, M.A., 2000. Relation of water transport to leaf gas exchange properties in three 18 mangrove species. Trees-Structure and Function, 14(5): 258-262.

19 Sobrado, M.A., 2001a. Effect of high external $\mathrm{NaCl}$ concentration on the osmolality of

20 xylem sap, leaf tissue and leaf glands secretion of the mangrove Avicennia

21 germinans (L.) L. Flora, 196(1): 63-70.

22 Sobrado, M.A., 2001b. Hydraulic properties of a mangrove Avicennia germinans as

23 affected by NaCl. Biologia Plantarum, 44(3): 435-438. 
1 Sobrado, M.A., 2005. Leaf characteristics and gas exchange of the mangrove Laguncularia racemosa as affected by salinity. Photosynthetica, 43(2): 217-221.

3 Sobrado, M.A., 2006. Differential leaf gas exchange responses to salinity and drought in

4 the mangrove tree Avicecennia germinans (Avicenniaceae). Revista De Biologia Tropical, 54(2): 371-375.

6 Sobrado, M.A., 2007. Relationship of water transport to anatomical features in the mangrove Laguncularia racemosa grown under contrasting salinities. New Phytologist, 173(3): 584-591.

9 Stapanian, M.A., Mack, J., Adams, J.V., Gara, B. and Micacchion, M., 2013. Disturbance

10 metrics predict a wetland vegetation index of biotic integrity. Ecological

11 Indicators, 24: 120-126.

12 Sternberg, L.D.L., Teh, S.Y., Ewe, S.M.L., Miralles-Wilhelm, F. and DeAngelis, D.L., 13 2007. Competition between hardwood hammocks and mangroves. Ecosystems, 14 10(4): 648-660.

15 Sternberg, L.d.S.L. and Swart, P.K., 1987. Utilization of freshwater and ocean water by 16 coastal plants of Southern Florida. Ecology, 68(6): 1898-1905.

17 Takemura, T., Hanagata, N., Sugihara, K., Baba, S., Karube, I. and Dubinsky, Z., 2000.

18 Physiological and biochemical responses to salt stress in the mangrove, Bruguiera 19 gymnorrhiza. Aquatic Botany, 68(1): 15-28.

20 Teh, S.Y., DeAngelis, D.L., Sternberg, L.D.L., Miralles-Wilhelm, F.R., Smith, T.J. and

21 Koh, H.L., 2008. A simulation model for projecting changes in salinity

22 concentrations and species dominance in the coastal margin habitats of the

23 Everglades. Ecological modelling, 213(2): 245-256. 
1 Tomlinson, P.B., 1994. The botany of mangroves. Cambridge University Press, Cambridge, 419 pp.

3 Torbick, N.M., Qi, J., Roloff, G.J. and Stevenson, R.J., 2006. Investigating impacts of 4 land-use land cover change on wetlands in the Muskegon River Watershed, 5 Michigan, USA. Wetlands, 26(4): 1103-1113.

6 van Duijn, C., Galiano, G. and Peletier, M., 1997. How mangroves salinize the soil. $7 \quad$ Citeseer.

8 Volkmar, K.M., Hu, Y. and Steppuhn, H., 1998. Physiological responses of plants to 9 salinity: A review. Canadian Journal of Plant Science, 78(1): 19-27.

10 Walker, B., Holling, C.S., Carpenter, S.R. and Kinzig, A., 2004. Resilience, adaptability 11 and transformability in social--ecological systems. Ecology and society, 9(2): 5.

12 Wei, L.L., Yan, C.L., Guo, X.Y. and Ye, B.B., 2008a. Variation in the delta(13)C of two 13 mangrove plants is correlated with stomatal response to salinity. Journal of Plant $14 \quad$ Growth Regulation, 27(3): 263-269.

15 Wei, L.L., Yan, C.L., Ye, B.B. and Guo, X.Y., 2008b. Effects of salinity on leaf delta C16 in three dominant mangrove species along salinity gradients in an estuarine 17 wetland, southeast China. Journal of Coastal Research, 24(1): 267-272.

18 Welch, R., Madden, M. and Doren, R.F., 1999. Mapping the everglades.

19 Photogrammetric Engineering and Remote Sensing, 65(2): 163-170.

20 Wiegand, T., Camarero, J.J., Rüger, N. and Gutiérrez, E., 2006. Abrupt population 21 changes in treeline ecotones along smooth gradients. Journal of Ecology, 94(4): $22 \quad 880-892$. 
1 Williams, K., MacDonald, M. and Sternberg, L.d.S.L., 2003. Interactions of storm,

2 drought, and sea-level rise on coastal forest: A case study. Journal of Coastal

$3 \quad$ Research, 19(4): 1116-1121.

4 Wilson, J.B. and Agnew, D.Q., 1992. Positive-feedback switches in plant communities. Advances in Ecological Research, 23: 263-336.

6 Ye, Y., Tam, N.F.Y., Lu, C.Y. and Wong, Y.S., 2005. Effects of salinity on germination,

$7 \quad$ seedling growth and physiology of three salt-secreting mangrove species. Aquatic

$8 \quad$ Botany, 83(3): 193-205.

9 Youssef, T., 2007. Stomatal, biochemical and morphological factors limiting

10 photosynthetic gas exchange in the mangrove associate Hibiscus tiliaceus under

11 saline and and environment. Aquatic Botany, 87(4): 292-298.

12 Youssef, T. and Saenger, P., 1999. Mangrove zonation in Mobbs Bay, Australia.

13 Estuarine Coastal and Shelf Science, 49: 43-50.

14

15

16 


\section{Figure captions}

2 Figure. 1. A map of southern Everglades National Park classifying vegetation types into mangrove, hardwood hammocks and others.

4 Figure 2. Percentage of transpiration reduction in response to a10 ppt increase of

14 Figure 3. Schematic diagram showing that the physical template controls soil salinity while, simultaneously, the mangrove has a positive effect on soil salinity, which has a negative effect of freshwater plant growth. The freshwater plant is assumed to be a superior competitor against mangrove under low salinity conditions. 


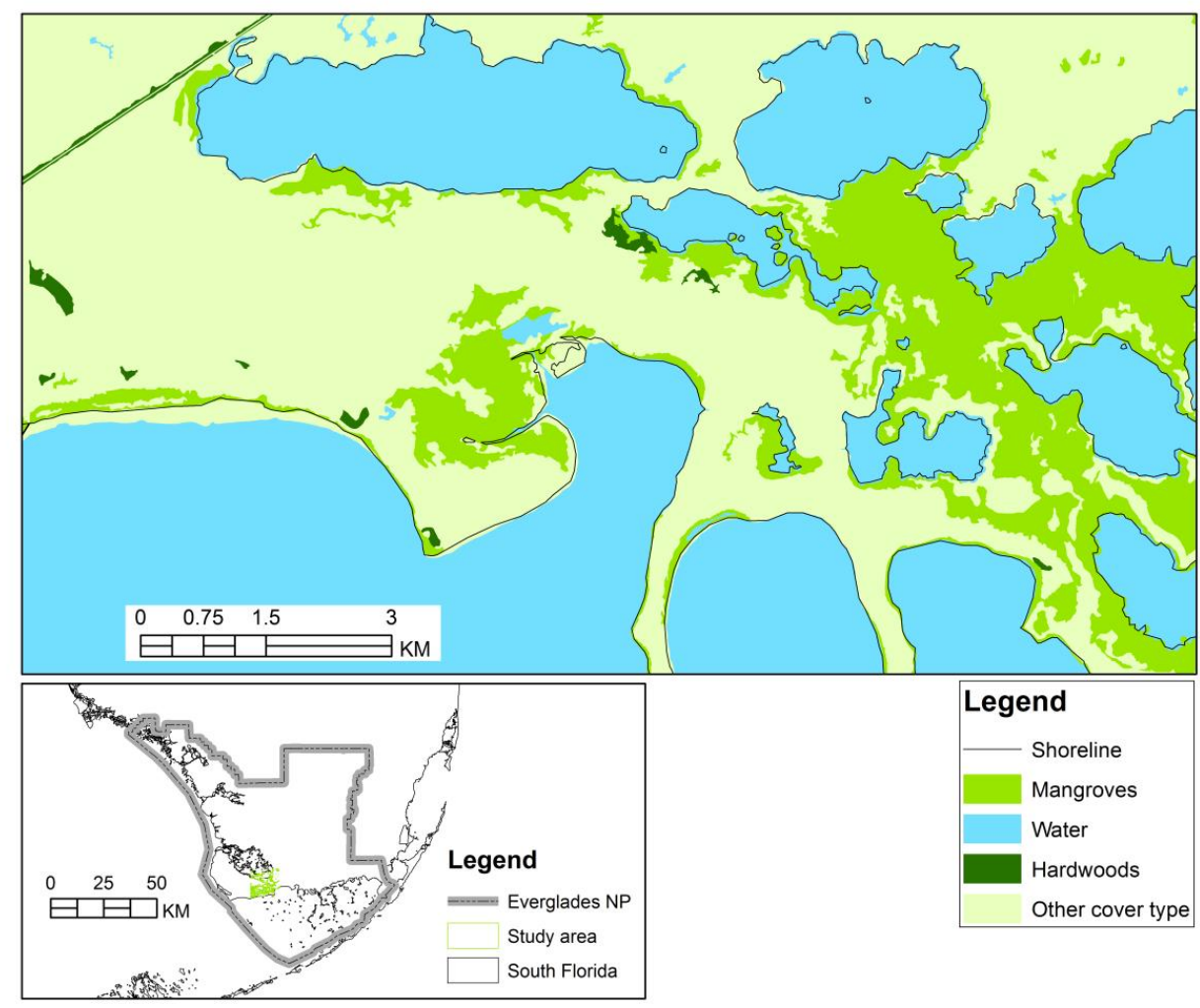

3

$4 \quad$ Figure 1.

5

6

7

8

9

10

11

12 
4

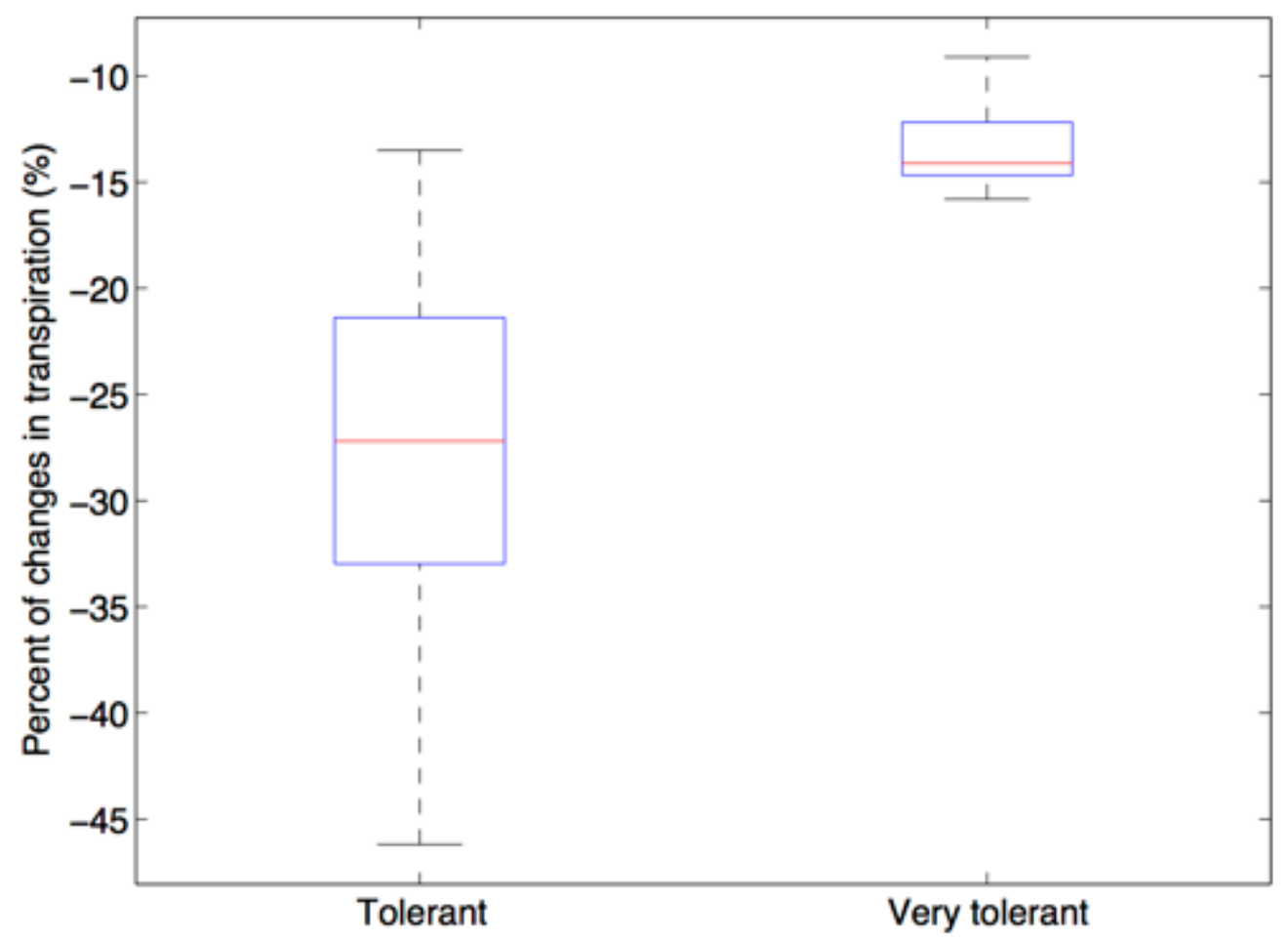

7 Figure 2.

8

9

10

11

12

13

14 


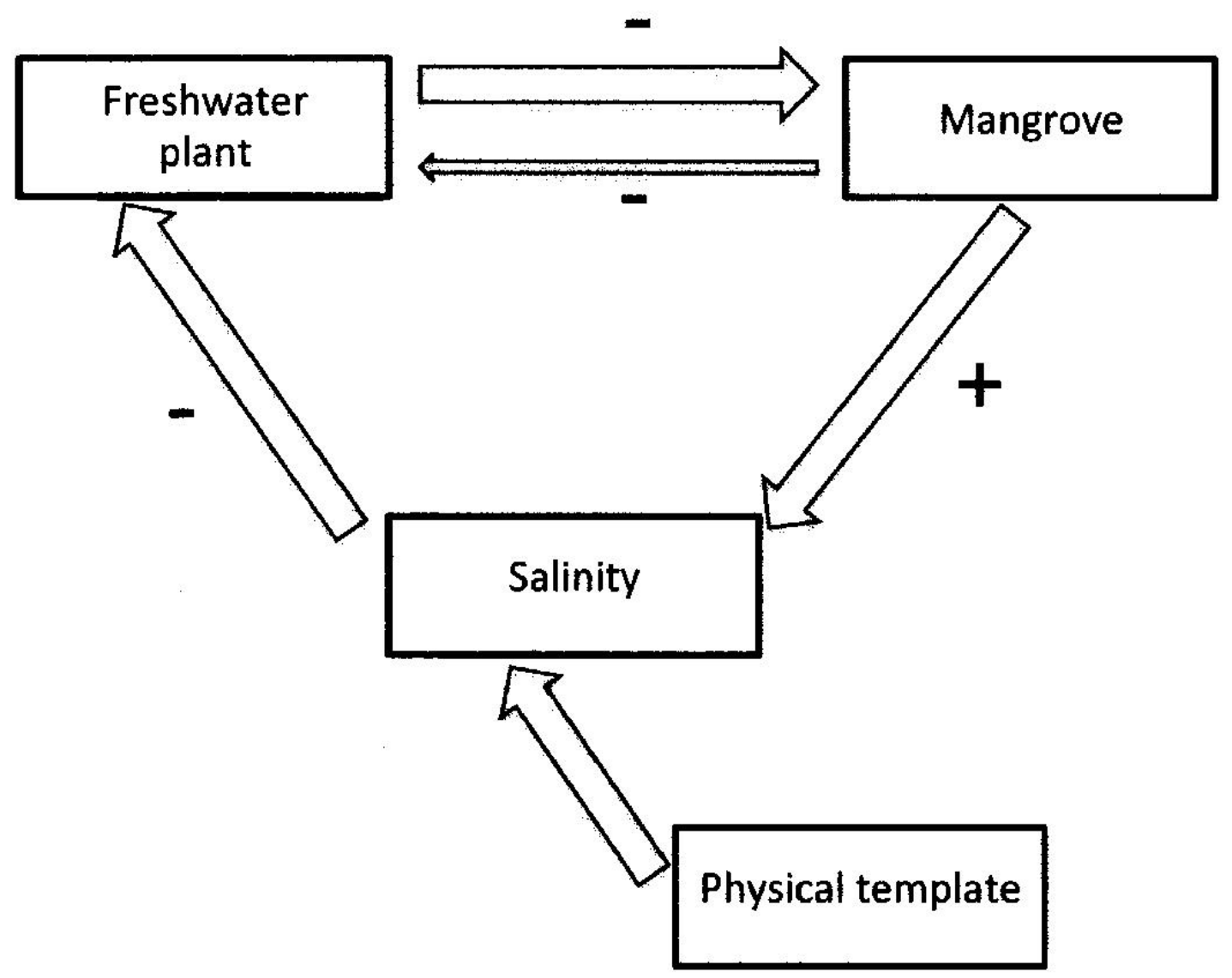

3

4

$5 \quad$ Figure 3.

6

7

8

9

10

11

12 


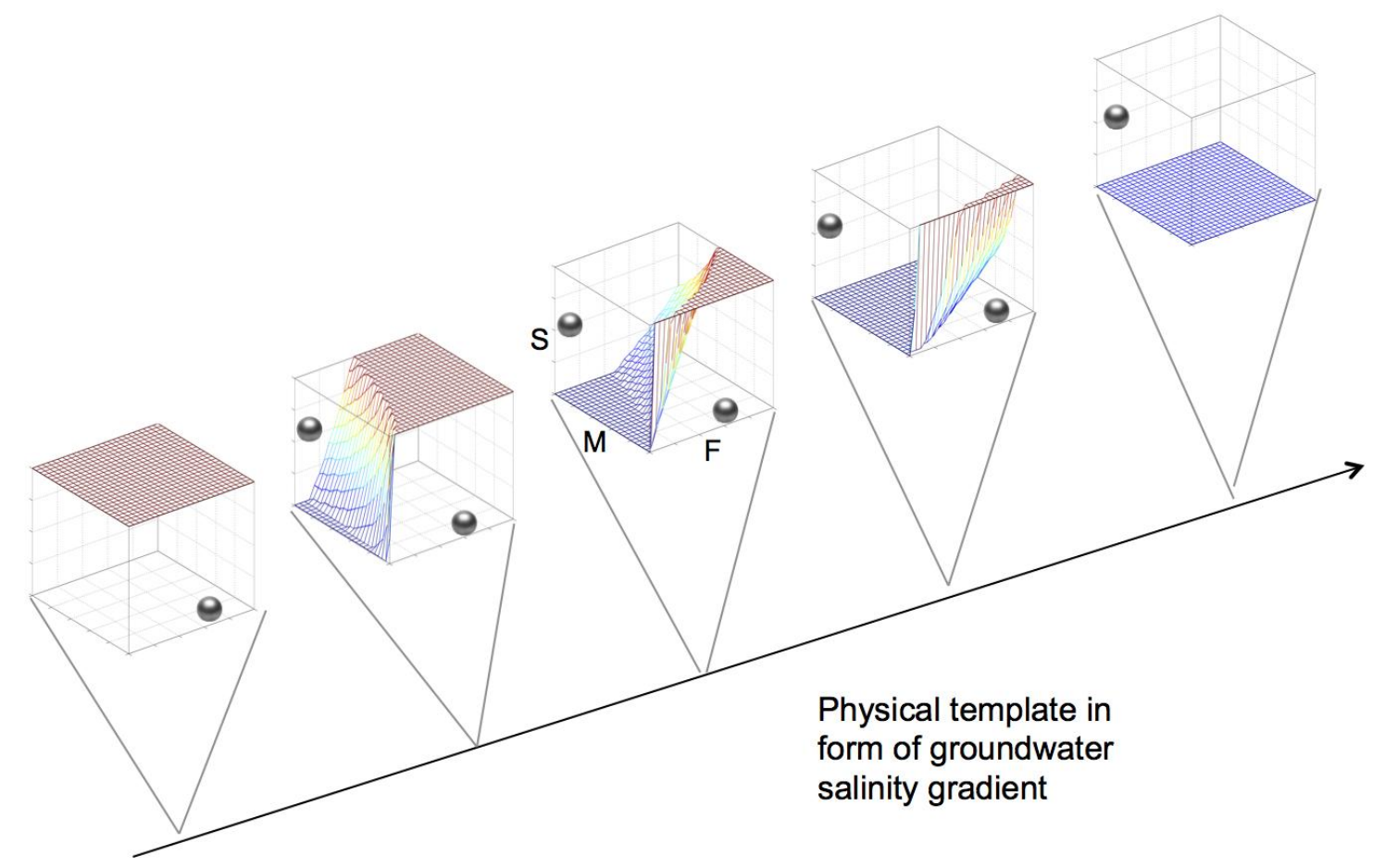

5

6 Figure 4. 